\title{
CHOICE AND OTHER DETERMINANTS OF EMPLOYEE CONTRIBUTIONS TO DEFINED CONTRIBUTION PLANS
}

\author{
Leslie E. Papke* \\ CRR WP 2004-06 \\ Released: March 2004 \\ Draft Submitted: February 2004 \\ Center for Retirement Research at Boston College \\ 550 Fulton Hall \\ 140 Commonwealth Ave. \\ Chestnut Hill, MA 02467 \\ Tel: 617-552-1762 Fax: 617-552-1750 \\ http://www.bc.edu/crr
}

* Leslie E. Papke is a Professor of Economics at Michigan State University. The research reported herein was performed pursuant to a grant from the U.S. Social Security Administration (SSA) to the Center for Retirement Research at Boston College (CRR). This grant was awarded through the CRR's Steven H. Sandell Grant Program for Junior Scholars in Retirement Research. The opinions and conclusions are solely those of the authors and should not be construed as representing the opinions or policy of the SSA or any agency of the Federal Government or of the CRR.

(C) 2004, by Leslie E. Papke. All rights reserved. Short sections of text, not to exceed two paragraphs, may be quoted without explicit permission provided that full credit, including $(\subset$ notice, is given to the source. 


\section{About the Center for Retirement Research}

The Center for Retirement Research at Boston College, part of a consortium that includes parallel centers at the University of Michigan and the National Bureau of Economic Research, was established in 1998 through a grant from the Social Security Administration. The goals of the Center are to promote research on retirement issues, to transmit new findings to the policy community and the public, to help train new scholars, and to broaden access to valuable data sources. Through these initiatives, the Center hopes to forge a strong link between the academic and policy communities around an issue of critical importance to the nation's future.

\section{Center for Retirement Research at Boston College}

550 Fulton Hall

140 Commonwealth Ave.

Chestnut Hill, MA 02467

phone: 617-552-1762 fax: 617-552-1750

e-mail: crr@bc.edu

http://www.bc.edu/crr

Affiliated Institutions:

American Enterprise Institute

The Brookings Institution

Massachusetts Institute of Technology

Syracuse University

Urban Institute 


\begin{abstract}
Understanding the role that $401(\mathrm{k})$ plan characteristics - like investment choice - play in participation and employee contributions is important as more workers rely on this type of retirement plan and proposals for Social Security solvency include individual savings plans. Using the 1992 Health and Retirement Study, this paper investigates which individual and job characteristics are associated with asset choice in defined contribution plans. Investment choice is found to substantially increase contributions to defined contribution plans.
\end{abstract}




\section{Introduction}

The striking growth of 401(k) plans has vastly expanded the number of individuals with some discretion regarding the retirement assets in their employer-provided pension plan. In 1998, the most recent year for which the U.S. Department of Labor (2003) has released detailed information from Internal Revenue Service (IRS) Form 5500 filings, about 83 percent (30.93 million) of the 37 million participants in 401(k) plans had some control over their investments. These participants owned over $\$ 1.25$ trillion in assets, accounting for 81 percent of 401(k) assets. Participants usually direct the investment of their own contribution, and often that of their employer. The decision to contribute is important for retirement income since usually an account is not even established for the employee unless

a contribution is made. Understanding the role that plan characteristics -- like investment choice -- play in participation is critical as more workers rely on this type of retirement plan. This paper presents evidence from the 1992 Health and Retirement Study on the prevalence of choice over pension investments and the effect of asset choice on contribution rates.

Recent work points to the importance of plan features in encouraging plan participation and contribution rates. These characteristics include the presence and size of an employer match rate, the fraction of salary matched, participant choice over asset allocation, and loan provisions. Plan features may have unintended consequences as well. For example, the structure of many 401(k) plans (often the employer contribution is made in company stock) may encourage employees to hold extremely risky portfolios - their pension assets as well as their human capital in one company.

Participant-friendly features like asset choice and loan provisions may encourage or maintain participation levels during periods where companies discontinue their contributions to 401(k) plans, for example. Since 2001, a number of large companies have either suspended or discontinued their employer match. ${ }^{1}$ These companies include Ford Motor Company, DaimlerChrysler, Goodyear, and Charles Schwab \& Co. Active control over plans assets may keep participants engaged in the plan - 
perhaps increasing their own contributions to cover the loss of the match - and allow plans to pass nondiscrimination requirements relatively inexpensively.

The behavior of participants in self-directed individual retirement accounts is relevant as well in the discussions of privatization of Social Security with individual savings accounts. Further, if future Social Security benefits are reduced, there will be an increased role for personal saving in financing retirement with tax deferred plans unrelated to employment like Individual Retirement Accounts (IRAs).

The next section provides background information on asset choice in pension plans and federal regulations governing investment options offered. I survey some recent work on the importance of plan features in plan participation. Section 3 presents estimates of the determinants of assets choice, and the effect of asset choice on contribution rates. There is a brief conclusion.

\section{Asset Choice in Pension Plans}

Prior to the availability of 401(k) plans, supplemental DC plans were organized as saving and thrift plans where the employee made contributions out of after-tax dollars. Employees were generally allowed to direct their contribution, but it was common for the employer's contribution to be constrained -- often to company stock. Many of these saving and thrift plans were converted when 401(k) plans became available (generally, 1981) to allow employee pre-tax contributions, but different treatment of the employer contribution continued. The extent of asset choice depends on the organizational form of the plan as well. In some 401(k) forms, even the employee contribution is required to be in company stock. For example, initial investment in company stock is common in profitsharing plans, and it is required for those organized as Employee Stock Option Plans. ${ }^{2}$

Companies are encouraged to provide a diverse offering of assets by Section 404(c) of the federal regulations pertaining to fiduciary responsibility. Section 404(c) of the Employee Retirement Income Security Act (ERISA), finalized in 1992, provides conditions under which the sponsor is not 
liable for loss or breach of fiduciary responsibility that may result from the participant's exercise of control over assets. Broadly, the participant must be able to "exercise independent control" over assets in the account. The sponsor must (1) provide sufficiently varied investment alternatives to allow the participant an opportunity to materially affect the potential returns on assets and account risk; (2) allow the participant to choose from at least three alternative investments, each of which must be diversified and each with different risk/return characteristics (employer's securities may not be one of the three); (3) provide sufficient information for the participant to make investment decisions; (4) allow the participant to change investments with a frequency that is appropriate for the expected market volatility of the investment ${ }^{3}$.

Perhaps due in part to this regulation, participant direction has grown over the decade of 1990s. Wiatrowski (2000) summarizes the trends in investment choice for full-time employees using several years of the Bureau of Labor Statistics National Compensation Survey. He reports that, in 1985, 90 percent of full-time employees had investment choice over their own contribution, and 48 percent had control over their employer's contribution. By 1997, there was a slight drop in the percentage who could control their own contributions (87 percent), but over 65 percent had choice over their employers' contribution. Using these data, Wiatrowski also finds that a smaller percentage of participants may choose company stock as an investment option. In 1985, for example, 70 percent of employees could choose employer stock for their contribution, and 61 percent could choose employer stock for their employer's contribution. In 1997, 42 percent could choose it for their contribution, and 25 percent could choose it for their employer's contribution.

Recent work relates plan features to participation. Using the 1998 Survey of Consumer Finances, Munnell, Sundén, and Taylor (2001) find that the ability to borrow from the plan increases the 401(k) contribution percentage by about one percentage point. Englehardt and Kumar (2003) estimates an elasticity of $401(\mathrm{k})$ contributions with respect to the employer match rate of 0.25 , suggesting employee contributions are responsive to matching. In recent work with two data sets -- 
1992 National Longitudinal Survey of Mature Women and Wave 1 of the 1992 Health and Retirement Study -- Papke (2003) estimates economically large effects of asset choice on the likelihood of participation, contribution rates, and account balances. Her preferred OLS estimates from that paper indicate that participants with choice are about 30 percent more likely to make a contribution to their defined contribution plan. She estimates that participants contribute between one and three percentage points more of salary annually, and they have at least $\$ 9,000$ more in their accounts than comparable participants without investment choice.

Other work indicates that participants often do not change the default choices firms make for them. Choi, Laibson, Madrian, and Metrick (2002), using administrative data from three companies with automatic enrollment in their 401(k) plans, find that most employees stay with a plan's pre-selected default contribution rate and the default investment fund chosen by the company. It appears that participant-friendly features like borrowing and investment choice are associated with a higher probability of participating and higher contribution levels. In the next section, I examine which job and individual characteristics are associated with the choice plan feature, and estimate the effect of choice on contributions.

\section{Econometric Estimates}

This section presents estimates of the determinants of pension plan investment choice and the effect of asset choice on contributions. I use data on pre-retirement age pension participants from Wave 1 (1992) of the Health and Retirement Study (HRS). The respondents are age 51-61 in 1992.

The 1992 HRS is a detailed survey that includes pension questions on up to three defined benefit (DB) and three defined contribution (DC) plans. I restrict the sample to those defined contribution participants who answer the following question about each of their defined contribution plans: Were you able to choose how the money in your account is invested? In the typical regression, 
there are 1,690 individual DC plan participants, with 180 multiple plans, for a total of 1,870 observations.

Note that the HRS question does not distinguish employer from employee contributions explicitly, so it is possible that the employee would report having choice over his contribution, even if the employer directs the firm's contributions. Unfortunately, there is no firm-reported pension information available in the publicly available HRS data.

\subsection{Determinants of Choice}

In this section, I relate individual characteristics, and the limited firm characteristics available in the HRS, to the participant-reported ability to choose pension investments. ${ }^{4}$ Table 1 presents summary statistics for this HRS sample. About 59 percent of the 1,983 respondents report having choice over investments in their pension plan, and they contribute, on average, about 5.05 percent of salary. Single women comprise about 13 percent of the sample, single men about seven percent, married women 32 percent, and about 48 percent are married men. The average age in the sample is 54 years. About 58 percent of this sample reports having an Individual Retirement Account (IRA), and 42 percent have a defined benefit pension plan in addition to their DC plan - either with the current or a former employer.

What individual and job characteristics are associated with defined contribution plans that offer asset choice? Column (1) of Table 2 presents estimates of a linear probability model of choice as a function of individual and firm characteristics. The ability to choose pension investments does not appear to vary by gender or marital status (married men are the omitted category). Asset choice does increase with years of education - a participant with four more years of education has a 6.4 percentage points higher probability of having investment choice than a comparable participant. Family net worth between $\$ 250,000$ and $\$ 500,000$ is also associated with a 9.2 percentage point higher probability of having choice. 
The individual characteristic with the largest economic effect on the choice probability is having a DB plan - either with the current employer or with a previous job. Having a DB plan raises the probability of having asset choice in one's DC plan by 13.4 percentage points. This suggests that individuals with a taste for saving may select jobs that offer defined benefit plans or defined contribution plans with self-direction features. These individuals may save in other forms and would be able to choose pension assets to achieve their preferred asset allocation across tax-deferred and non-tax deferred accounts.

The probability of having choice also varies for a few industries and occupation categories (these coefficients are not reported in Table 2). Workers in public administration are estimated to be 17 percentage points more likely than workers in agriculture and mining to have choice in their pension plan (none of the other industry coefficients differed from the omitted category). Workers in service, farming and construction, and machine operator occupations are estimated to be significantly less likely to have choice than workers in managerial positions (from 10 to 24 percentage points).

I also include two sets of firm size dummies in the linear probability model of choice. The first set is based on the number of employees in the participant's work location, the second set is the participant's estimate of the firm's employment in all locations. The four included dummy variables are statistically significant in the choice equation, suggesting that participants in larger firms (more than 99 employees) are between seven and 10 percentage points more likely to have investment choice in their pension plan.

Since choice is a binary variable, I also estimate a probit model containing the same explanatory variables as in Table 2. The estimates, reported in column (1) of Table 3, are qualitatively similar to those from the linear probability model. In particular, the direction and statistical significance of the coefficients is the same. As in the linear probability model, firm size has an important effect on choice.

\subsection{Econometric Results for Employee Contribution Percentage}


Pension investment choice may affect the level of participation in a pension plan. Some behavioral theories of saving suggest that a change in the economic environment, such as requiring participants to choose assets in a pension plan, may stimulate saving. ${ }^{5}$ With employer-provided pensions in place, individuals are more likely to learn that others think saving is important. This section presents models explaining the employee's contribution percentage to the DC plan as a function of choice, and individual and employment characteristics. In this HRS sample, the average contribution percent is 5.05 percent of salary with a standard deviation of 4.81 . The median contribution is 5.00 percent, and the mean of those who contribute is 7.10 percent, with a standard deviation of 4.27. About 29 percent (573) report a zero contribution.

Simple tabulations indicate that participants are more likely to participate when investment choice is present. While 50.37 percent of those without choice report a zero contribution, only 13.76 of those without choice report a zero contribution.

Column (2) of Table 2 presents estimates of linear models of the percent of salary the participant contributes to his or her DC plan. OLS estimates are in column (2). Standard errors are corrected for heteroskedasticity. Controlling for individual characteristics, financial characteristics, and industry and occupation, choice over pension assets is estimated to increase the annual contribution by 2.9 percentage points. This increase, a 43 percent increase relative to the unconditional mean contribution of 5.05 percent, is an economically large effect and is precisely measured.

Having a DB plan or an IRA also increases the percent contributed. These dummy variable coefficients indicate a taste for saving - a participant with a DB plan is predicted to contribute about 1.5 percentage points more to his or her DC plan. The sign of the coefficient on the IRA dummy is also positive, but is imprecisely measured. The percent of salary contributed is greater for each included income and net worth category relative to the omitted categories (income less than $\$ 25,000$ and net worth less than $\$ 50,000$ ) - but the difference is generally close to one percentage point. (The largest 
effect is 1.8 percentage points for the $\$ 250-500 \mathrm{~K}$ net worth category.) This suggests that the benefits of tax deferred saving, in percentage terms at least, are fairly evenly spread among the medium to highincome participants.

These OLS estimates indicate that participant-direction of pension assets has a statistically significant and economically large effect on pension contributions. However, one might argue that choice is an endogenous variable in these regressions. That is, participants with some financial sophistication and taste for saving join firms that offer plans with investment choice. Unobserved saving heterogeneity may remain in the error term despite my attempt to control for saving propensity by including the ownership of an IRA and participation in a DB plan. Pension plans with participantdirection features may be more common in certain industries and occupations - I include those dummy variables as well to allow individuals to sort on that basis. Unfortunately, there are a limited number of pension plan features in the publicly available HRS data.

Ideally, we could find one or more instrumental variables (IV) for the choice variable in the contribution equation. Such a variable must be exogenous in the contribution equation - that is, it must be properly omitted from the equation and it must be uncorrelated with unobservables, such as taste variables, in that equation. In addition, the IV candidates must be partially correlated with choice. Instrumental variables are difficult to come by without some kind of natural experiment that would exogenously cause some firms to offer choice when they might not have otherwise. In the publicly available HRS, the possibilities are rather limited. Nevertheless, the results for the linear probability choice models are suggestive. In particular, firm size has a significant effect on choice. It may also be reasonable to assume that, while individuals with a taste for saving may select different industry and occupations, there is no systematic sorting of those with a taste for saving into certain firm sizes - either at their work location or number of employees in the entire firm. As with most applications of instrumental variables, this assumption can be questioned. However, I can partly test exogeneity of the firm size variables via a test of the overidentifying restrictions; I report the results below. 
Column (3) of Table 2 contains two stage least squares (2SLS) estimates of the contribution equation, where the four firm size dummies included in Column (1) are used as IVs for choice. The 2SLS estimate of the effect of choice is substantially larger than the OLS estimate, suggesting that a participant with choice contributes over 8.5 percentage points more annually to their DC plan than a comparable participant without choice. This effect is estimated fairly precisely, and it is the largest effect. Single and married women are estimated to contribute more (.83 and 1.03 percentage points, respectively) than married men. Older participants contribute more, but the effect is quite small economically. Participants with higher income and higher net worth are estimated to contribute about one percentage point more than the lowest income and net worth categories, as in the OLS estimates. The 2SLS coefficient on the DB indicator is positive, but not statistically significant. Apparently, the real causal effect of having a DB plan is zero.

The difference between the OLS and 2SLS estimates of the choice coefficient are practically large. Nevertheless, as the 2SLS standard error is about 10 times larger than the OLS standard error, the difference between OLS and 2SLS could be due to sampling error. This is not the case here. I use a regression-based Hausman test, made robust to heteroskedasticity, to determine whether the difference between OLS and 2SLS is statistically significant. The statistic is computed by obtaining the reduced form residuals from the linear probability model for choice and then including these as a regressor in the contribution equation. The expanded equation is estimated by OLS, and the heteroskedasticity-robust $\mathrm{t}$ statistic on the reduced form residuals is a valid test statistic. Assuming that the firm size dummies are exogenous, the null hypothesis is that choice is exogenous. A significant $t$ statistic on the reduced form residuals rejects exogeneity of choice (Wooldridge (2000). When I carry out this test, the coefficient on the reduced form residual is -5.513 and its p-value is .001, suggesting that the unobservables affecting choice are actually negatively correlated with unobservables in the error in the structural model. 
The story about unobserved taste for saving being positively correlated with choice means we would expect OLS to be upward biased. On average, then, we would expect the 2SLS estimate to be smaller than the OLS estimate. There are several reasons the opposite might occur. First, of course, firm size might not be exogenous, in which case the 2SLS estimates could have an upward bias. (I offer a test of this below.) If firm size is positively correlated with unobserved taste for saving, we expect an upward bias. Because the correlation between choice and firm size is not perfect, a modest amount of correlation between firm size and taste for saving can lead to a large asymptotic bias in 2 SLS ${ }^{6}$. A second possibility is that choice is measured with error, in which case OLS could have a downward bias. Unfortunately, the direction of bias for OLS is unclear in this application, as choice is a binary variable that cannot satisfy the classical errors-in-variables model. Still, when IV estimates are unexpectedly higher than OLS estimates, measurement error is often cited as a possibility.

A third, more subtle, possibility comes from the treatment effect literature. In a simple bivariate setting, Imbens and Angrist (1994) characterize the probability limit of the IV estimator of the treatment effect of a binary endogenous explanatory variable. In my application, the Imbens and Angrist results imply that the IV estimator consistently estimates the average effect for those participants whose choice status is induced by a change in firm size. It could be that this effect is larger than for the population as a whole $^{7}$.

Since I have one endogenous variable - choice - and four instruments (the firm size dummies in Column (1) of Table 2), I am able to test the three overidentifying restrictions. The heteroskedasticityrobust regression-based statistic is 5.036. Under the null hypothesis that all IVs are uncorrelated with the structural error, this is the outcome of a chi-square random variable with three degrees of freedom; the p-value is about .167 , so the firm size dummies pass the overidentification test if we use standard significance levels ${ }^{8}$.

Finally, rather than using a standard 2SLS procedure, where the reduced form of choice is linear, I use the fitted choice probabilities from the probit model in Table 3 as a single IV for choice in 
the contribution equation. This is the most efficient IV, since the fitted probabilities are the best predictor of choice. These IV estimates are reported in Table 3 (Column 2); they are generally similar to the 2SLS estimates in Table 2.

\section{Conclusion}

In this paper, I use an instrumental variable approach to the problem of potential endogeneity of investment choice in a contribution equation. My preferred estimates indicate that a participant with choice contributes over 8.5 percentage points more annually to their DC plan than a comparable participant without choice. This is an economically large effect - the unconditional mean of contributions is around five percentage points of salary. I also find that the benefits of tax deferred saving are distributed fairly evenly across income levels.

From a policy perspective, it is important to understand what plan features encourage employee participation in defined contribution plans. This paper adds to a growing literature that suggests that plan attributes other than the employer match rate can play a role in increasing participant contributions. Loan provisions and asset choice may encourage contributions even as employers reduce or eliminate matching provisions in their 401(k) plans. 


\section{References}

Bernheim, B.D. (1997), "Rethinking Saving Incentives," in Auerbach, A.J. (ed), Fiscal Policy:

Lessons from Economic Research. MIT Press, Cambridge and London, 259-311.

Choi, J., Laibson, D., Madrian, B., and Metrick, A. "For Better or for Worse: Default Effects and 401(k) Savings Behavior.” NBER Working Paper 8651.

Employee Benefit Research Institute. 1997. Fundamentals of Employee Benefit Programs, fifth ed., Employee Benefit Research Institute, Washington D.C.

Engelhardt, G.V., Kumar, A. (2003), "Understanding the Impact of Employer Matching on 401(k) Saving,” TIAA-CREF Institute, Research Dialog 76, June 2003.

Gustman, A.L., and Steinmeier, T. (2004), "What People Don't Know About Their Pensions and Social Security.” In W. G. Gale, J.B. Shoven, and M.J. Warshawsky, eds., Private Pensions and Public Policies, Washington, D.C., Brookings Institution, 57-125.

Imbens, G.W. and Angrist, J.D. (1994), "Identification and Estimation of Local Average Treatment Effects," Econometrica 62, 467-476.

Munnell, A.H., Sundén, A. and Taylor, C. (2001), "What Determines 401(k) Participation and Contributions?" Boston College, mimeo.

Munnell, A.H., A. Sundén, (2003), "Suspending the Employer 401(k) Match,” Issue Brief Number 12, Center for Retirement Research at Boston College, June.

Papke, L.E., (2003). "Individual Financial Decisions in Retirement Plans: The Role of ParticipantDirection," Journal of Public Economics 88, 39-61.

Thaler, R.H., and Shefrin, H (1981), “An Economic Theory of Self-Control”, Journal of Political Economy 89, 392-406.

U.S. Department of Labor, Bureau of Labor Statistics. 1990. Employee Benefits in Medium and Large Firms, 1989. Bulletin 2363, June.

U.S. Department of Labor, Pension and Welfare Benefits Administration. 2002. Abstract of 1998 Form 5500 Annual Reports. Private Pension Plan Bulletin Number 11, Winter.

Wiatrowski, W.J. (2000), "Putting Stock in Benefits: How Prevalent Is It?" Compensation and Working Conditions, Fall, 2-7.

Wooldridge, J.M. (2000), Introductory Econometrics: A Modern Approach. Cincinnati, OH: South-Western. 
Wooldridge, J.M. (2002), Econometric Analysis of Cross Section and Panel Data. Cambridge, MA: MIT Press. 


\begin{tabular}{|c|c|c|c|}
\hline & Mean & Standard Deviation & Observations \\
\hline Choice & .589 & .492 & 1983 \\
\hline Contribution percentage & 5.050 & 4.831 & 1981 \\
\hline Single female & .128 & .334 & 1981 \\
\hline Single male & .071 & .257 & 1981 \\
\hline Married female & .318 & .466 & 1969 \\
\hline Age & 54.456 & 4.850 & 1981 \\
\hline Education & 13.488 & 2.542 & 1981 \\
\hline Income $25-50 \mathrm{~K}$ & .302 & .459 & 1981 \\
\hline Income $50-100 \mathrm{~K}$ & .441 & .497 & 1981 \\
\hline Income $>100 \mathrm{~K}$ & .168 & .374 & 1981 \\
\hline Net worth $50-100 \mathrm{~K}$ & .189 & .391 & 1981 \\
\hline Net worth $100-250 \mathrm{~K}$ & .351 & .478 & 1981 \\
\hline Net worth $250-500 \mathrm{~K}$ & .182 & .386 & 1981 \\
\hline Net worth > 500K & .094 & .292 & 1981 \\
\hline Has IRA & .581 & .494 & 1981 \\
\hline Has DB & .421 & .494 & 1981 \\
\hline \multicolumn{4}{|l|}{ Industry dummies: } \\
\hline Ag.\& Mining & .046 & .210 & 1908 \\
\hline Manufacturing & .275 & .446 & 1908 \\
\hline Transportation & .096 & .295 & 1908 \\
\hline Wholesale & .048 & .213 & 1908 \\
\hline Retail & .074 & .262 & 1908 \\
\hline FIRE \& Services & .403 & .491 & 1908 \\
\hline Public Admin. & .059 & .235 & 1908 \\
\hline \multicolumn{4}{|l|}{ Occupation dummies } \\
\hline Management & .238 & .426 & 1922 \\
\hline Prof., spec.\&tech. & .200 & .400 & 1922 \\
\hline Sales & .079 & .269 & 1922 \\
\hline Clerical & .209 & .406 & 1922 \\
\hline Services & .049 & .217 & 1922 \\
\hline Farming/construction & .027 & .162 & 1922 \\
\hline Operators & .198 & .399 & 1922 \\
\hline Emp. Here $<99$ & .450 & .498 & 1913 \\
\hline $100<=$ Emp. Here $<=499$ & .276 & .447 & 1913 \\
\hline Emp. Here $>=500$ & .273 & .446 & 1913 \\
\hline Firm size $<=99$ & .166 & .372 & 1904 \\
\hline $100<=$ Firm size $<=499$ & .162 & .369 & 1904 \\
\hline Firm size $>500$ & 672 & .470 & 1904 \\
\hline
\end{tabular}


Table 2. Linear Probability Model of Choice \&

Linear Models of Participant's Contribution Percentage to Defined Contribution Plan

\begin{tabular}{|c|c|c|c|}
\hline & $(1)$ & $(2)$ & (3) \\
\hline Dependent Variable: & Choice & $\begin{array}{c}\text { Percent Contributed } \\
(\text { OLS })\end{array}$ & $\begin{array}{c}\text { Percent Contributed } \\
\text { (2SLS) }\end{array}$ \\
\hline Choice & & $\begin{array}{l}2.936^{* * * *} \\
(.214)\end{array}$ & $\begin{array}{c}8.551^{* * *} \\
(2.027)\end{array}$ \\
\hline Single female & $\begin{array}{l}-.050 \\
(.041) \\
\end{array}$ & $\begin{array}{l}.579^{*} \\
(.355)\end{array}$ & $\begin{array}{c}.825^{*} \\
(.429)\end{array}$ \\
\hline Single male & $\begin{array}{c}.020 \\
(.049) \\
\end{array}$ & $\begin{array}{l}.547^{* * *} \\
(.395)\end{array}$ & $\begin{array}{c}.441 \\
(.450)\end{array}$ \\
\hline Married female & $\begin{array}{l}-.032 \\
(.030)\end{array}$ & $\begin{array}{l}.832^{* * *} \\
(.284)\end{array}$ & $\begin{array}{l}1.032^{* * *} \\
(.339)\end{array}$ \\
\hline Age & $\begin{array}{l}-.00011 \\
(.0024)\end{array}$ & $\begin{array}{l}.076^{* * * *} \\
(.021)\end{array}$ & $\begin{array}{l}.080^{* * *} \\
(.026)\end{array}$ \\
\hline Education & $\begin{array}{l}.016^{* * *} \\
(.0057)\end{array}$ & $\begin{array}{l}-.036 \\
(.053)\end{array}$ & $\begin{array}{l}-.132^{*} \\
(.072)\end{array}$ \\
\hline Income $25-50 \mathrm{~K}$ & $\begin{array}{l}-.016 \\
(.045)\end{array}$ & $\begin{array}{l}.932^{* * *} \\
(.350)\end{array}$ & $\begin{array}{l}.995^{* *} \\
(.440)\end{array}$ \\
\hline Income $50-100 \mathrm{~K}$ & $\begin{array}{c}.011 \\
(.048)\end{array}$ & $\begin{array}{l}1.175^{* * *} \\
(.392)\end{array}$ & $\begin{array}{l}1.059^{* *} \\
(.479)\end{array}$ \\
\hline Income $>100 \mathrm{~K}$ & $\begin{array}{c}.015 \\
(.056) \\
\end{array}$ & $\begin{array}{l}1.005^{* *} \\
(.497)\end{array}$ & $\begin{array}{l}.845^{* * *} \\
(.598) \\
\end{array}$ \\
\hline Net worth $50-100 \mathrm{~K}$ & $\begin{array}{c}.045 \\
(.038) \\
\end{array}$ & $\begin{array}{l}.657^{* *} \\
(.302) \\
\end{array}$ & $\begin{array}{c}.352 \\
(.402) \\
\end{array}$ \\
\hline Net worth $100-250 \mathrm{~K}$ & $\begin{array}{c}.043 \\
(.036)\end{array}$ & $\begin{array}{l}1.045^{* * *} \\
(.302)\end{array}$ & $\begin{array}{l}.732^{* * *} \\
(.399)\end{array}$ \\
\hline Net worth $250-500 \mathrm{~K}$ & $\begin{array}{l}.092^{* *} \\
(.042) \\
\end{array}$ & $\begin{array}{l}1.806^{* * *} \\
(.387)\end{array}$ & $\begin{array}{l}1.234^{* *} \\
(.504)\end{array}$ \\
\hline Net worth $>500 \mathrm{~K}$ & $\begin{array}{c}.057 \\
(.053)\end{array}$ & $\begin{array}{l}.900^{*} \\
(.488)\end{array}$ & $\begin{array}{c}.589 \\
(.566)\end{array}$ \\
\hline Has DB & $\begin{array}{l}.134^{* * * *} \\
(.025)\end{array}$ & $\begin{array}{l}1.451^{* * *} \\
(.228)\end{array}$ & $\begin{array}{c}.540 \\
(.423) \\
\end{array}$ \\
\hline Has IRA & $\begin{array}{c}.025 \\
(.026)\end{array}$ & $\begin{array}{c}.141 \\
(.227)\end{array}$ & $\begin{array}{c}.049 \\
(.273)\end{array}$ \\
\hline $100<=$ Emp. Here $<=499$ & $\begin{array}{c}.072^{* * *} \\
(.030)\end{array}$ & & \\
\hline Emp. Here $>=500$ & $\begin{array}{c}.071^{* * *} \\
(.031)\end{array}$ & & \\
\hline $100<=$ Firm size $<=499$ & $.074^{*}$ & & \\
\hline
\end{tabular}




\begin{tabular}{|l|c|c|c|}
\hline & $(.043)$ & & \\
\hline Firm size > 500 & $.107^{* * *}$ & & \\
& $(.038)$ & Yes & Yes \\
\hline $\begin{array}{l}\text { Industry \& occupation } \\
\text { dummies }\end{array}$ & Yes & -4.320 & -5.513 \\
\hline Constant & .151 & $(1.503)$ & $(1.886)$ \\
& $(.176)$ & 1,888 & 1,865 \\
\hline Observations & 1,865 & .1980 & \\
\hline $\mathrm{R}^{2}$ & .1084 & & \\
\hline
\end{tabular}

Notes: Standard errors that are robust to heteroskedasticity and to correlation across multiple plans for an individual are in parentheses. A coefficient marked with three (two, or one) asterisks is statistically significant at the one, five, or ten percent level. 


\begin{tabular}{|c|c|c|}
\hline \multicolumn{3}{|c|}{ Linear Model of Participant's Contribution Percentage to Defined Contribution Plan } \\
\hline Dependent variable: & Choice & $\begin{array}{l}\text { Percent Contributed } \\
\text { (IV) }\end{array}$ \\
\hline Choice & & $\begin{array}{l}9.096^{* * *} \\
(2.001) \\
\end{array}$ \\
\hline Single female & $\begin{array}{l}-.137 \\
(.110)\end{array}$ & $\begin{array}{l}.847^{*} \\
(.441)\end{array}$ \\
\hline Single male & $\begin{array}{c}.067 \\
(.132) \\
\end{array}$ & $\begin{array}{l}.427 \\
(.463) \\
\end{array}$ \\
\hline Married female & $\begin{array}{l}-.085 \\
(.083) \\
\end{array}$ & $\begin{array}{l}1.052^{* * *} \\
(.347) \\
\end{array}$ \\
\hline Age & $\begin{array}{l}-.00062 \\
(.0068)\end{array}$ & $\begin{array}{l}.081^{* * * *} \\
(.027)\end{array}$ \\
\hline Education & $\begin{array}{l}.045^{* * *} \\
(.016) \\
\end{array}$ & $\begin{array}{l}-.141^{*} \\
(.073) \\
\end{array}$ \\
\hline Income $25-50 \mathrm{~K}$ & $\begin{array}{l}-.047 \\
(.120) \\
\end{array}$ & $\begin{array}{l}1.0006^{* *} \\
(.455) \\
\end{array}$ \\
\hline Income $50-100 \mathrm{~K}$ & $\begin{array}{r}.019 \\
(.129) \\
\end{array}$ & $\begin{array}{l}1.046^{* *} \\
(.494) \\
\end{array}$ \\
\hline Income $>100 \mathrm{~K}$ & $\begin{array}{c}.037 \\
(.156)\end{array}$ & $\begin{array}{c}.827 \\
(.615)\end{array}$ \\
\hline Net worth $50-100 \mathrm{~K}$ & $\begin{array}{c}.123 \\
(.101)\end{array}$ & $\begin{array}{l}.325 \\
(.415)\end{array}$ \\
\hline Net worth $100-250 \mathrm{~K}$ & $\begin{array}{l}.117 \\
(.099) \\
\end{array}$ & $\begin{array}{r}.703^{*} \\
(.411) \\
\end{array}$ \\
\hline Net worth $250-500 \mathrm{~K}$ & $\begin{array}{c}.263^{* * *} \\
(.120) \\
\end{array}$ & $\begin{array}{l}1.182^{* *} \\
(.517) \\
\end{array}$ \\
\hline Net worth $>500 \mathrm{~K}$ & $\begin{array}{c}.155 \\
(.150)\end{array}$ & $\begin{array}{l}.560 \\
(.581)\end{array}$ \\
\hline Has DB & $\begin{array}{l}.371^{* * * *} \\
(.068) \\
\end{array}$ & $\begin{array}{c}.452 \\
(.422) \\
\end{array}$ \\
\hline Has IRA & $\begin{array}{l}.068 \\
(.071)\end{array}$ & $\begin{array}{c}.040 \\
(.281)\end{array}$ \\
\hline $100<=$ Emp. Here $<=499$ & $\begin{array}{c}.202^{* * *} \\
(.082)\end{array}$ & \\
\hline Emp. Here $>=500$ & $\begin{array}{l}.203^{* *} \\
(.090) \\
\end{array}$ & \\
\hline $100<=$ Firm size $<=499$ & $\begin{array}{l}.191^{*} \\
(.113)\end{array}$ & \\
\hline Firm size $>500$ & $\begin{array}{l}.283^{* * *} \\
(.101)\end{array}$ & \\
\hline
\end{tabular}




\begin{tabular}{|l|c|c|}
\hline $\begin{array}{l}\text { Industry \& occupation } \\
\text { dummies }\end{array}$ & Yes & Yes \\
\hline Constant & -.952 & -5.636 \\
& $(.484)$ & $(1.940)$ \\
\hline Observations & 1,865 & 1,865 \\
\hline
\end{tabular}

Notes: Standard errors that are robust to heteroskedasticity and to correlation across multiple plans for an individual are in parentheses. A coefficient marked with three (two, or one) asterisks is statistically significant at the one, five, or ten percent level. 
${ }^{1}$ See Munnell and Sunden (2003) for a detailed discussion.

${ }^{2}$ ESOPs must invest primarily in qualified securities of the employer (debt instruments are not included). Plan administrators must allow participants nearing retirement to diversify at least 25 percent of the account (see EBRI, 1997). Stock-option plans and stock purchase plans (the latter provides employees the opportunity to purchase company stock at a discount) are not tax-qualified defined contribution plans.

${ }^{3}$ See Section Number 2550.404c-1, Rules and Regulations for Fiduciary Responsibility, ERISA section 404(c) plans of the Code of Federal Regulations Pertaining to PWBA at www.dol.gov/dol/allcfr/pwba.

${ }^{4}$ Prior research finds that many participants may not understand their pension arrangements (see, for example, Gustman and Steinmeier (2004)) which is an important caveat about HRS self-reported pension data.

${ }^{5}$ See Thaler and Shifrin (1981). Bernheim (1997) compares behavioral theories of saving to those that come from the traditional life cycle hypothesis.

${ }^{6}$ See, for example, Wooldridge (2000), Section 15.1 for a discussion.

${ }^{7}$ Wooldridge (2000), Section 18.4.2 discusses the Imbens and Angrist (1994) characterization in this setting.

${ }^{8}$ Unfortunately, this test tends to have low power because it is effectively based on comparing two different IV estimates. See Wooldridge (2002), Section 6.2.2. 


\section{RECENT WORKING PAPERS FROM THE \\ Center For Retirement Research at Boston College}

Living Arrangements and Supplemental Security Income Receipt Among the Aged Melissa M. Favreault and Douglas A. Wolf, February 2004

Interactions Between Social Security Reform and the Supplemental Security Income Program for the Aged

Paul S. Davies and Melissa M. Favreault, February 2004

Supply-Side Consequences of Social Security Reform: Impacts on Saving and Employment

Barry Bosworth and Gary Burtless, January 2004

It's All Relative: Understanding the Retirement Prospects of Baby-Boomers

Barbara A. Butrica, Howard M. Iams, and Karen E. Smith, November 2003

The Notional Defined Contribution Model: An Assessment of the Strengths and Limitations of a New Approach to the Provision of Old Age Security

John B. Williamson and Matthew Williams, October 2003

Simulating the Distributional Consequences of Personal Accounts: Sensitivity to Annuitization Options

Cori E. Uccello, Melissa M. Favreault, Karen E. Smith, and Lawrence H. Thompson, October 2003

Aggregate Implications of Defined Benefit and Defined Contribution Systems Francisco Gomes and Alexander Michaelides, September 2003

Can Unexpected Retirement Explain the Retirement-Consumption Puzzle? Evidence for Subjective Retirement Explanations Melvin Stephens Jr. and Steven J. Haider, August 2003

Employment, Social Security and Future Retirement Outcomes for Single Mothers Richard W. Johnson, Melissa M. Favreault, and Joshua H. Goldwyn, July 2003

The Outlook for Pension Contributions and Profits in the U.S. Alicia H. Munnell and Mauricio Soto, June 2003

Social Security Reform and the Exchange of Bequests for Elder Care Meta Brown, June 2003

All working papers are available on the Center for Retirement Research website (http://www.bc.edu/crr) and can be requested by e-mail (crr@bc.edu) or phone (617-552-1762). 